افزايش دز جذبى در روش فعال سازى فوتونى در بافت نشاندار شده با طلا و لوتتيم

* محمدرضا قاسمى

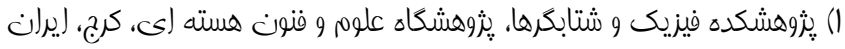

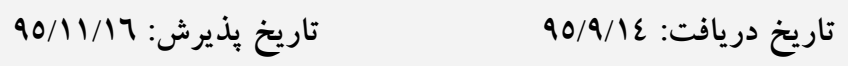

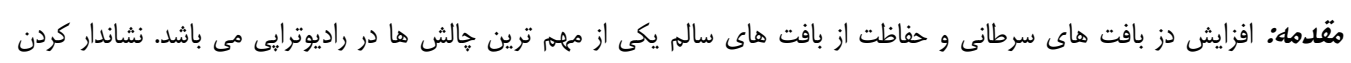

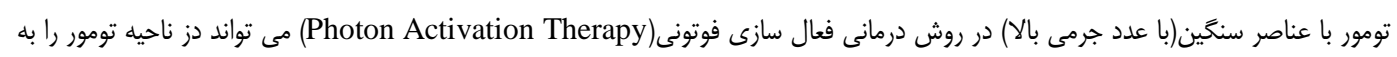

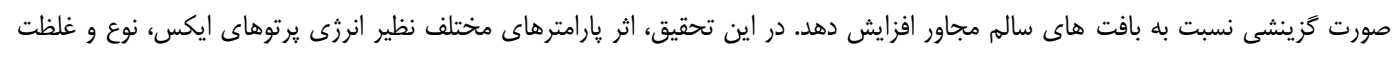
عوامل فعال ساز، در توزيع دز به منظور افزايش كيفيت درمان، توسط كد شبيه سازى مانى

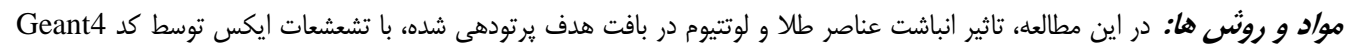

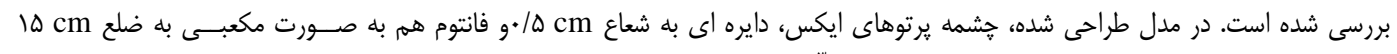

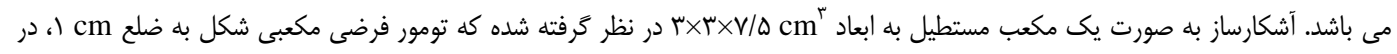
داخل آن قرار دارد.

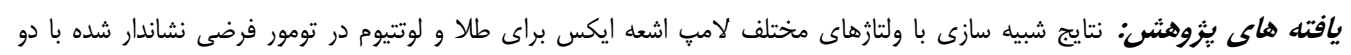

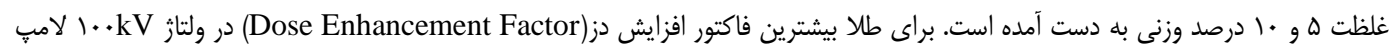

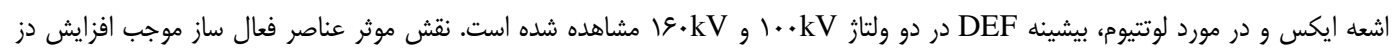

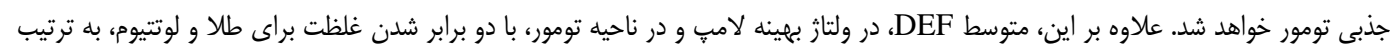

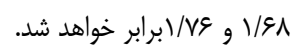

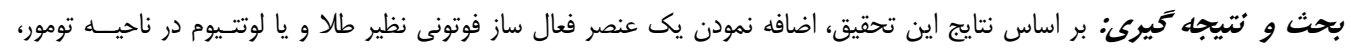

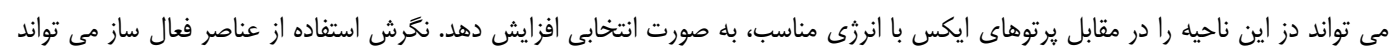

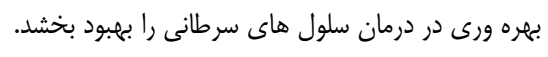

وازه هاى كليدى: درمان به روش فعال سازى فوتونى، فاكتور افزايش دز، كد Geant4، طلا، لوتتيوم، انرزى بهينه * نويسنده مسئول: ئووهشده فيزيك و شتابخرها، يُوهشخاه علوم و فنون هسته اى، كرج، ايران

Email:mghasemi842@gmail.com

Copyright (c) 2018 Journal of Ilam University of Medical Science. This is an open-access article distributed under the terms of the Creative Commons Attribution international 4.0 International License (https://creativecommons.org/licenses/by-nc/4.0/) which permits copy and redistribute the material, in any medium or format, provided the original work is properly cited. 


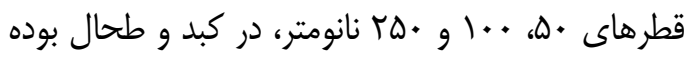

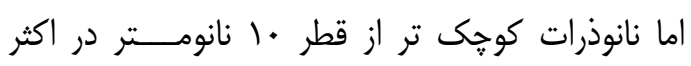

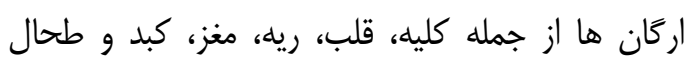

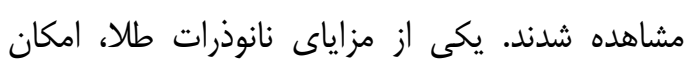

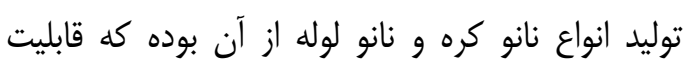

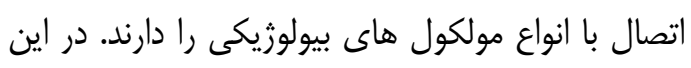
صورت، هدف گيرى بهتر تومور و عبور ساده تر از

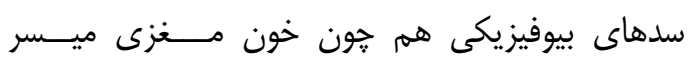
مى شود(9). يرتودهى با فوتون هاى ايكس و وجود عــناصر

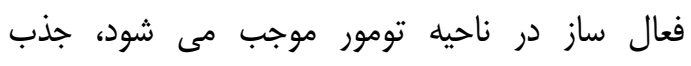

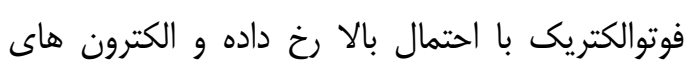

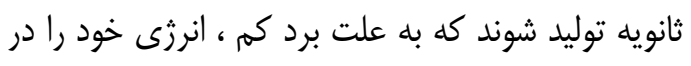

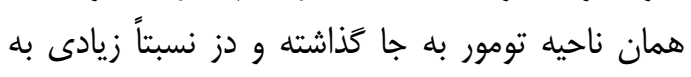
تومور وارد شده كه بازده درمان را افزايش خوان خواهد

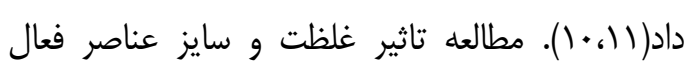
ساز نظير هلاتين، طلا و گادلونيوم، به ويزه با گَسترش

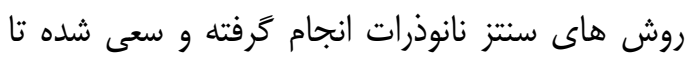
شرايط بهينه به دست آيد(أ(-r (1). علاوه بر اين يافتن عناصر جديد با كاركرد مناسب داسب در روش درمانى فعال سازى فوتونى جالش جالش جديدى باري

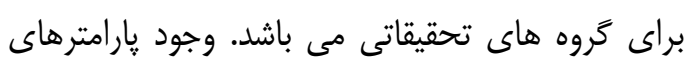
مختلف و شرايط فيزيكى متنوع در يرتودرمانى موجب تهري

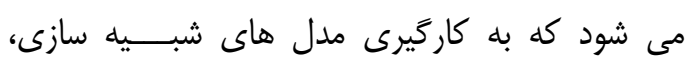

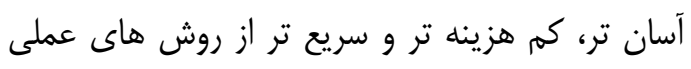

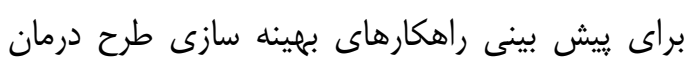

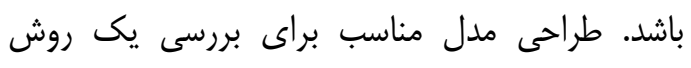

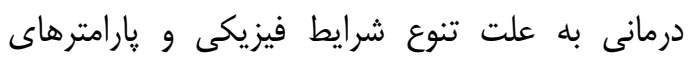

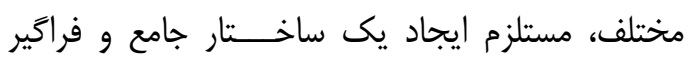

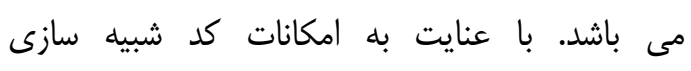

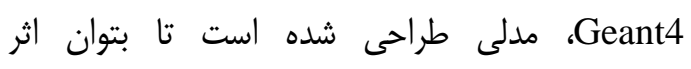

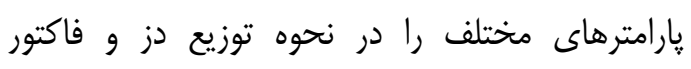
افزايش دز(Dose Enhancement Factor)، مطارئل

$$
\text { نمود. }
$$

در اين تحقيق، ميزان تاثير يارامترهاى مختلف نظير

انرزى برتوهاى ايكس، نوع و غلظت عنصر فعال ساز،

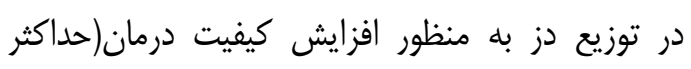
تخريب در بافت سرطانى و حداقل آسيب به بافت دريت دران
مقدمه

امروزه دانش و تكنولوزى، نانو ابزارهاى مفيد و

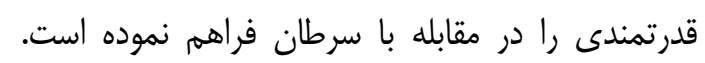

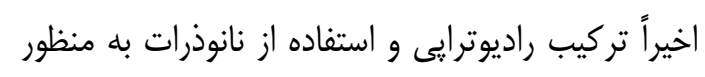

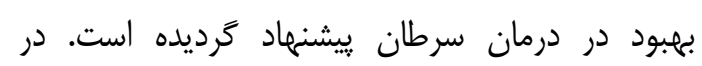
راديوترايى به صورت كسترده ایى از يرتوهاى ايكس و دراد

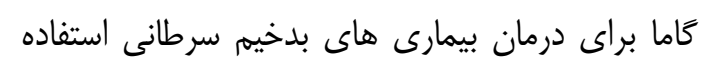

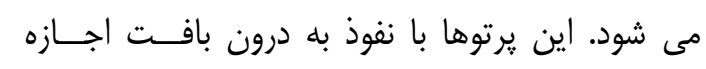

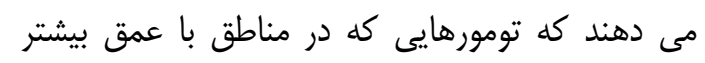

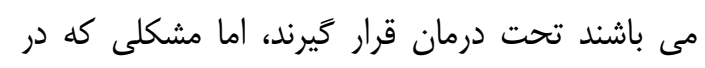

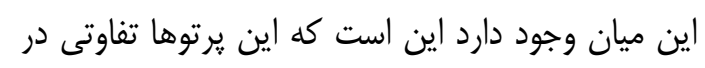

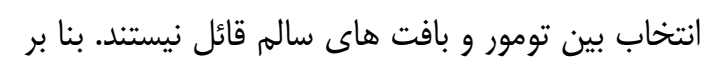

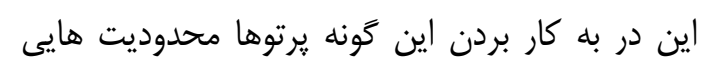

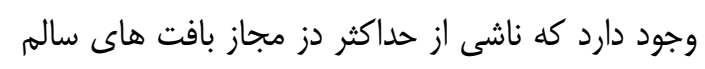
مجاور و يا در مسير يرتو مى باشد.

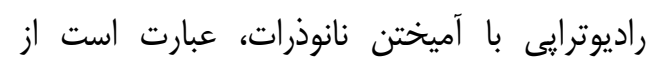

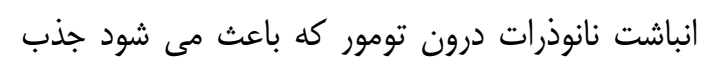

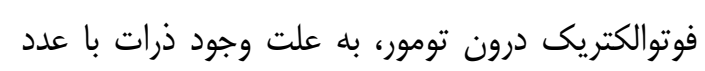

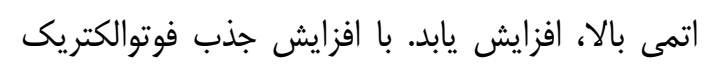

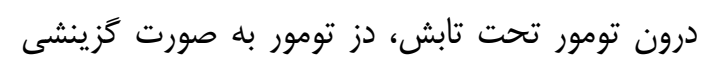
زياد مى شود بدون اين كه، دز بافت هاى سالم مجاور

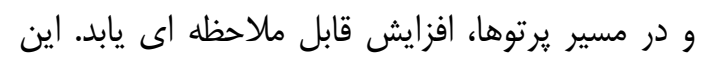

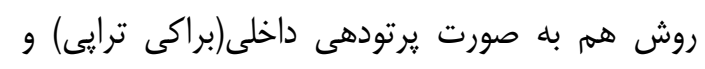
هم يرتودهى خارجى قابل انجام است(بأب-1).

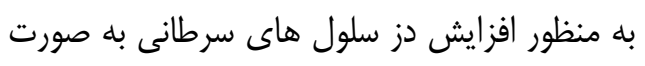

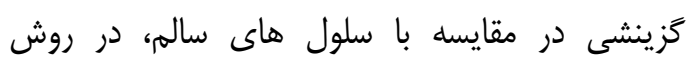
درمانى فعال سازى فوتونى( Photon Activation Therapy

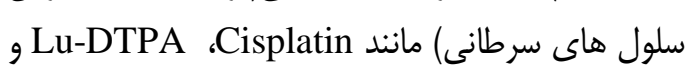
تزريق مى شود(D-VIdUed

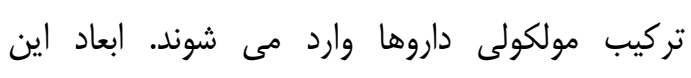
مولكول ها طورى سنتز مى شوند تا به دليل فعاليت

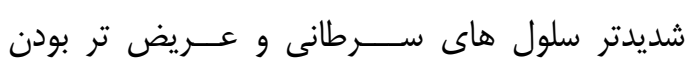

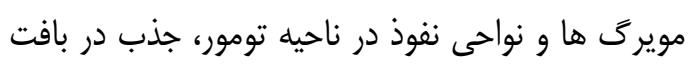
سرطانى، حداكثر باشد(^). مطالعه تجربى نشان داده كه اندازه نانوذرات و نحوه

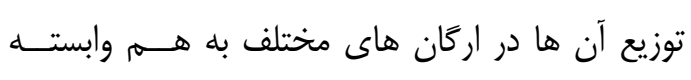

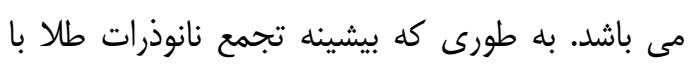


G4ParticleGun

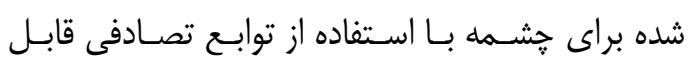
تعريف مى باشند. هندسه شامل محيط(فضايى كه همه

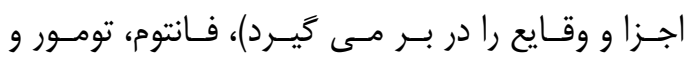

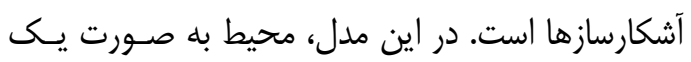

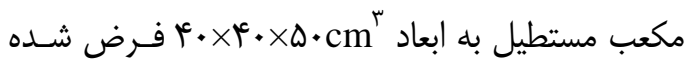

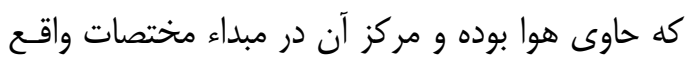

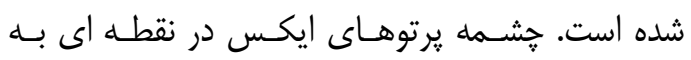

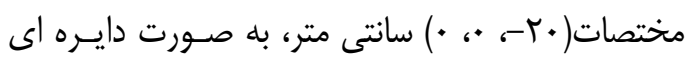

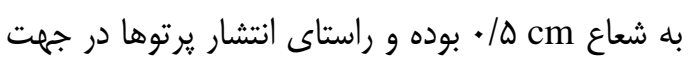
محور Z مى باشد(شكل شماره ().
سالم)، توسط كد شبيه سازى Geant4، مورد بررسى قرار گرفته است. توسط كل

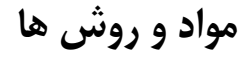

اجزاء مدل طراحى شده براى شبيه سازى درمان بـا

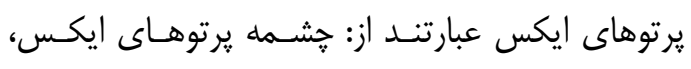

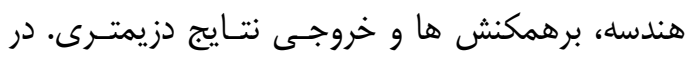
Geant4 G4VPrimerayGenerator

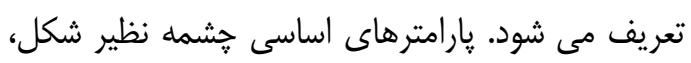

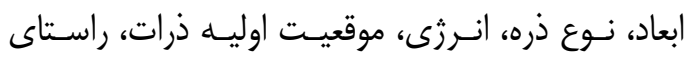

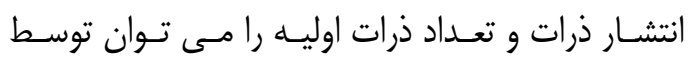

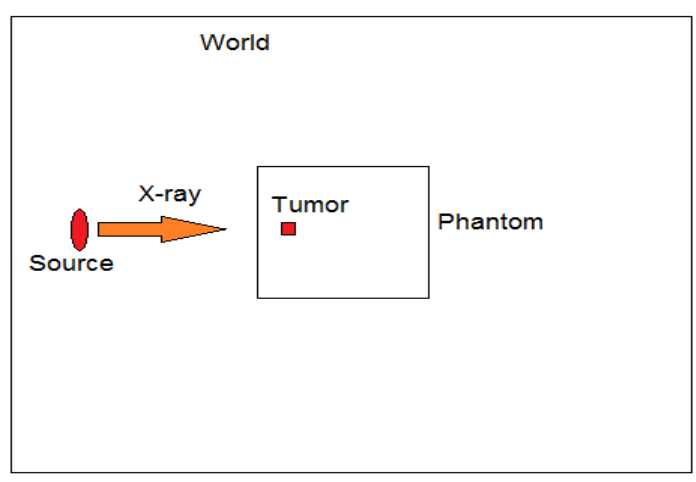

شكل شماره ا. جِيدمان اجزاء استفاده شده در شبيه سازى

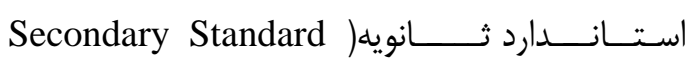
(DosimetryLaboratory

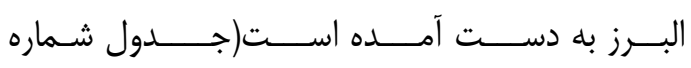

براى جشمه، از يرتوهاى يـك مولــ اشـعه ايكس

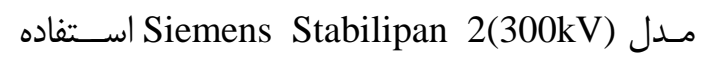

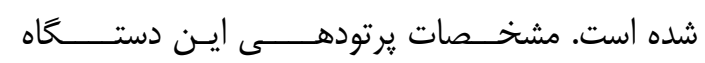

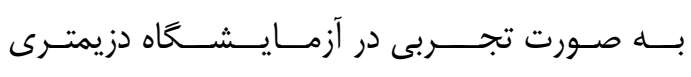

جدول شماره ا. مشخصات يرتوهاى ايكس مرجع توليد شده در سطح درمانى

\begin{tabular}{|c|c|c|c|c|c|c|c|}
\hline $\begin{array}{c}\text { ضريب كاليبراسيون } \\
\text { Nk,Monitor chamber } \\
(\mathrm{mGy} / \mathrm{nC}) \\
1 \cdot 1 \mathrm{bmm}, \mathrm{r} \text {. C }\end{array}$ & آهنخ تقريبى كرماى هوا & $\begin{array}{l}\text { انرزى موثر } \\
(\mathrm{keV})\end{array}$ & $\begin{array}{l}\text { h ضريب همخنى } \\
\text { (HVL1/HVL2) }\end{array}$ & $\begin{array}{l}\text { SVL كيفيت } \\
\text { (mm) }\end{array}$ & فيلتر اضافى(mm) & جريان(mA) & ولتاز (kV) \\
\hline | & 91 & $T V / T^{c}$ & $\cdot \mid 90$ & 1/9 Al & - & M & q. \\
\hline - TYKeq & $\Delta r$ & $r V /{ }^{c}$ & $\cdot / \mathrm{V}$ & $\Gamma / \varsigma \mathrm{Al}$ & $\mid \mathrm{Al}$ & $M$ & $\wedge$. \\
\hline . $\mid$ TrT. & $9 x^{c}$ & $\mathrm{~F} / \mathrm{T}$ & $\cdot / \Delta F$ & $\cdot / r \Delta \mathrm{Cu}$ & $|\mathrm{Cu}+| \mathrm{Al}$ & $M$ & $1 \ldots$ \\
\hline - /rAT. & $\Delta \Lambda$ & $\Delta 9 / 9$ & $\cdot / \Delta V$ & $\cdot / e^{2} \mathrm{Cu}$ & $r \mathrm{Cu}+1 \mathrm{Al}$ & If & ir. \\
\hline - / TYAT & $n$ & $W / s$ &.$|9|$ &.$/ 9 \vee \mathrm{Cu}$ & $\cdot / f^{c} \mathrm{Cu}+\mid \mathrm{Al}$ & 11 & 19. \\
\hline.$/ T I V$. & sV & $1.9 / 0$ &.$/ \mathrm{V}$ & 1/9r Cu & $1 / r \mathrm{Cu}+\backslash \mathrm{Al}$ & 11 & $r .$. \\
\hline
\end{tabular}


افزايش دز كه توسط فرمول ذيـل تعريـف مسى شـود، معيارى براى بررسى نقش عناصر مذكور در افـزايش دز جذبى تومور مى باشد(شكل شماره r).

كد Geant4 داراى فايل هاى متعددى براى محاسبه سطح مقطع برهمكنش هاى محتمل با توجه

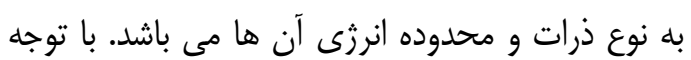

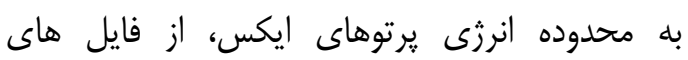

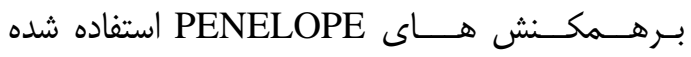
است(ه). كد مرجع و مورد استفاده در مركز شتابدهنده سرن، Geant4 مى باشد كه اعتبارسنجى و مقايسه

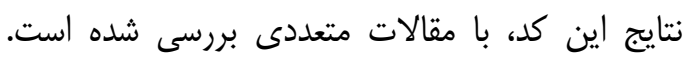
Amakoa كد Geant4 را بررسى نموده اند(1) (1). برهمكنش هاى فوتوالكتريك، يراكندگى همـدوس،

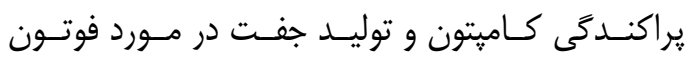
محتمل مى باشند كه توليد جفت كمترين احتمال وقوع

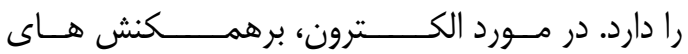

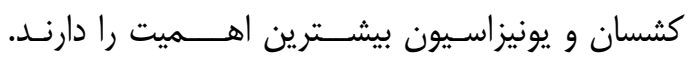

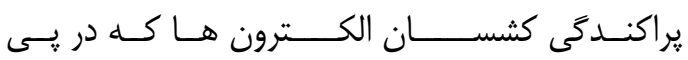

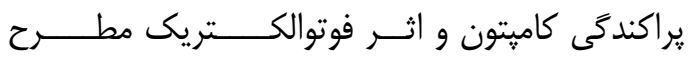
مى شـــــود، نقـش اساسـى در انتقـال انـرزى را دارد.

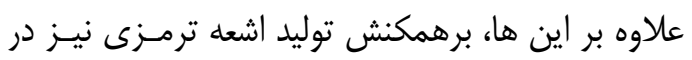

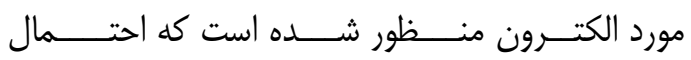

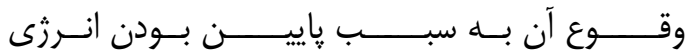

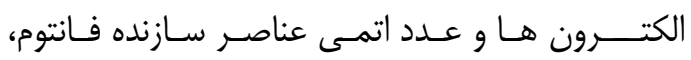
بســيار اندى است.
طيف انرزى فوتون هاى ساطع شـده در ولتازهـاى مختلف لامي اشعه ايكس جــزء اطلاعـات مـورد نيـاز براى شبيه سازى توزيع دز مى باشــــ از آن جـايى كـهـ

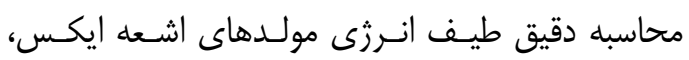

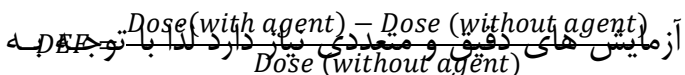

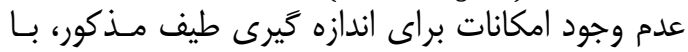

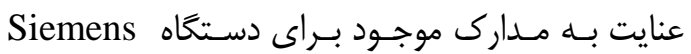
Stabilipan 2(300kV) شده در مرجع(IV)، طيف انرزى فوتون هاى ايكس در ولتازهاى مختلف، تخمين زده شد.

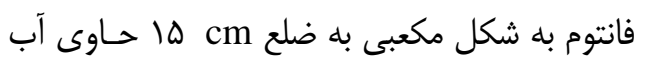

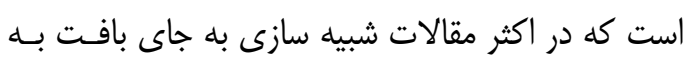

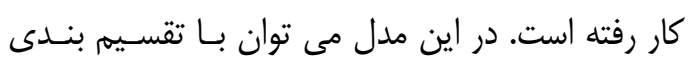

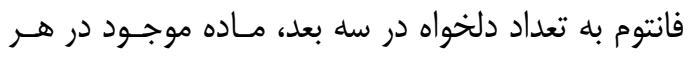
قسمت را بنـا بــر ضـرورت تغييـر داد. ايـن قابليـت، در مطالعه اثر تركيبات شيميايى تزريق شده به ناحيه تومور

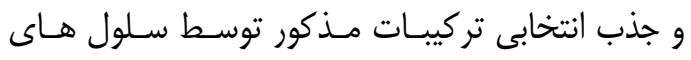
سرطانى، براى دز دريافتى ناشى از يرتـودهى بــا اشـعه

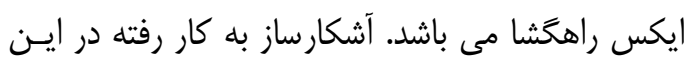
بررسى به صورت يك مكعب مستطيل است كه قابـل جايگذارى در هر نقطه اى از فانتوم بوده و مى توان آن را در راستاى محورهاى سه كانه مختصات، با توجه بــه قدرت تفكيك مورد نياز براى دزيمترى، تقسـيم بنـدى مولى كرد. تومور فرضى به صورت يك مكعب به ضلع است كه مختصات مركز آن(ه-، +، • • سانتى متـر و در

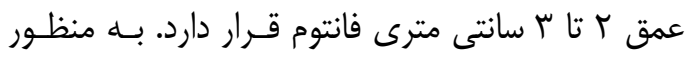

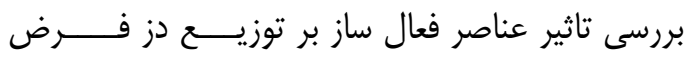
مى شود كه تومور مكعبى حاوى عنصر فعال ساز نظيـر

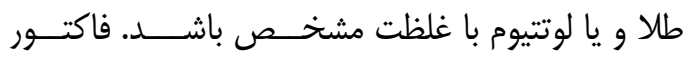

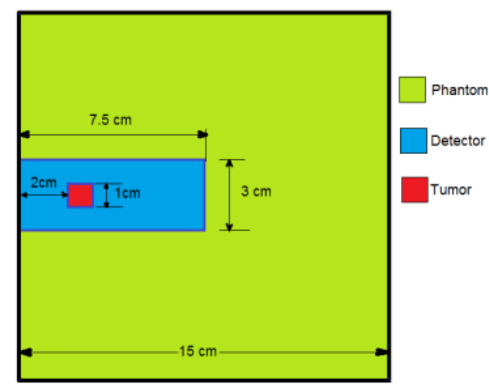

شكل شماره r. موقعيت تومور نسبت به فانتوم و ناحيه آشكارساز 


\section{يافته هاى يزوهش}

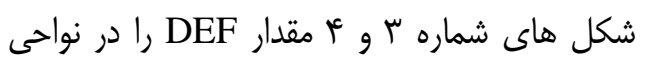

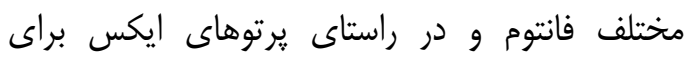
غلظت هاى ه و م. أ درصد طلا و با توجه به ولتاز

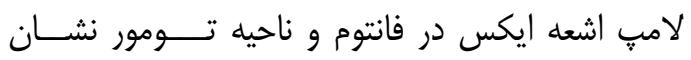
مى دهند. افزايش قابل ملاحظه دز در ناحيه تومور در

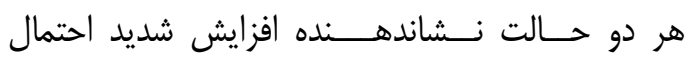

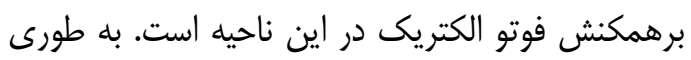

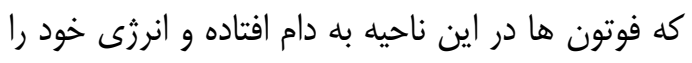
به الكترون هاى ثانويه با برد كم منتقل مى نى نمايند.

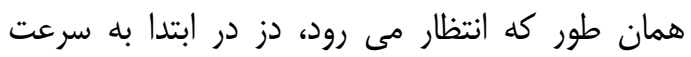

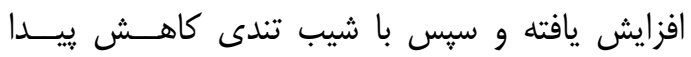
مى كند. معمولاً در هنعام درمان، ترجيح داده مى شى شود

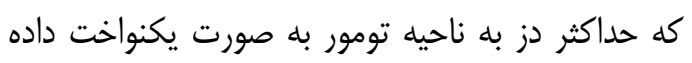
شود. در اين صورت مى توان با اطمينان بيشترى نسبت

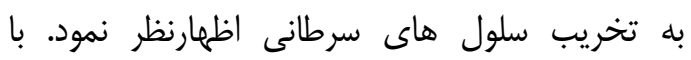
افزايش غلظت طلا، از يكنواختى توزيع دز كم شده اما سا

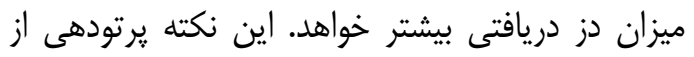

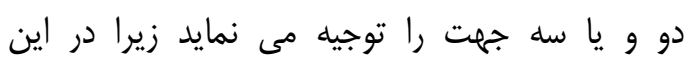

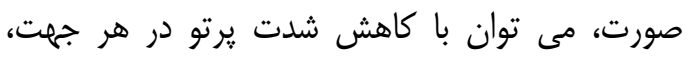

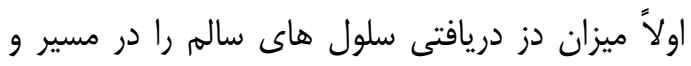
بعد از تومور كاهش داد و ثانياً توزيع دز ران را در ناحيه

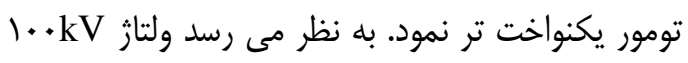
در هر دو غلظت علاوه بر DEF قابل توجه، توزيع تورد

$$
\text { يكنواخت ترى را مى دهد. }
$$

به منظور اجتناب از اتلاف زمـان در دنبـال كـردن

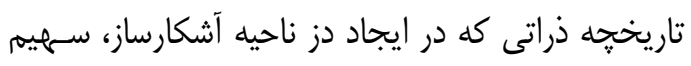

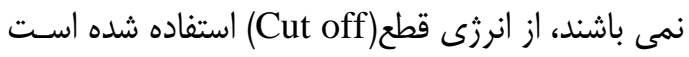
كه در Geant4 به صورت فاصله تعريف مى شـود. بــهـ

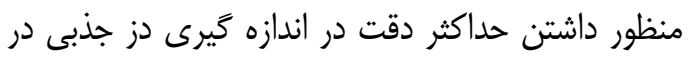

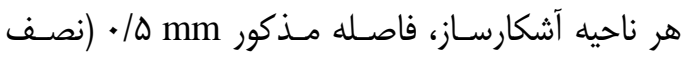

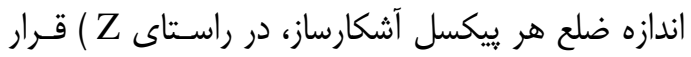
داده شده است. به منظور كاهش خطاى نتايج به دست

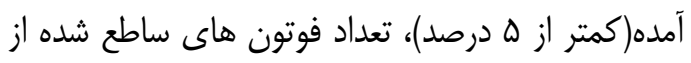

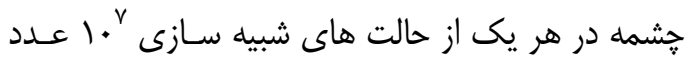
در نظر ترفته شده است. خروجى اصلى كد بـهـ صـورت

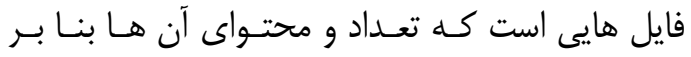
خواسته كاربر قابل تغيير است. اين فايل هـا بـهـ وسـيله

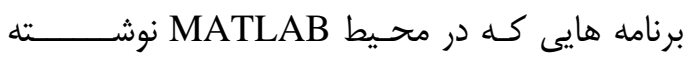

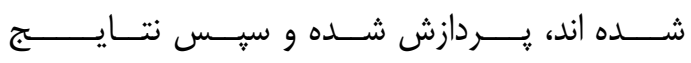

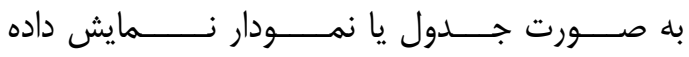

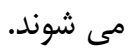

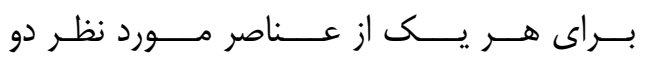

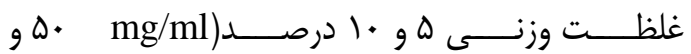

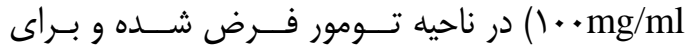

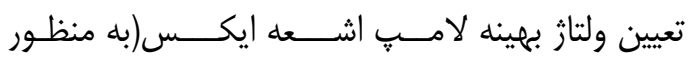

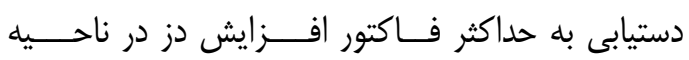

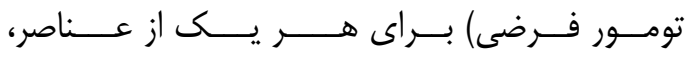

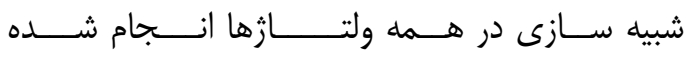

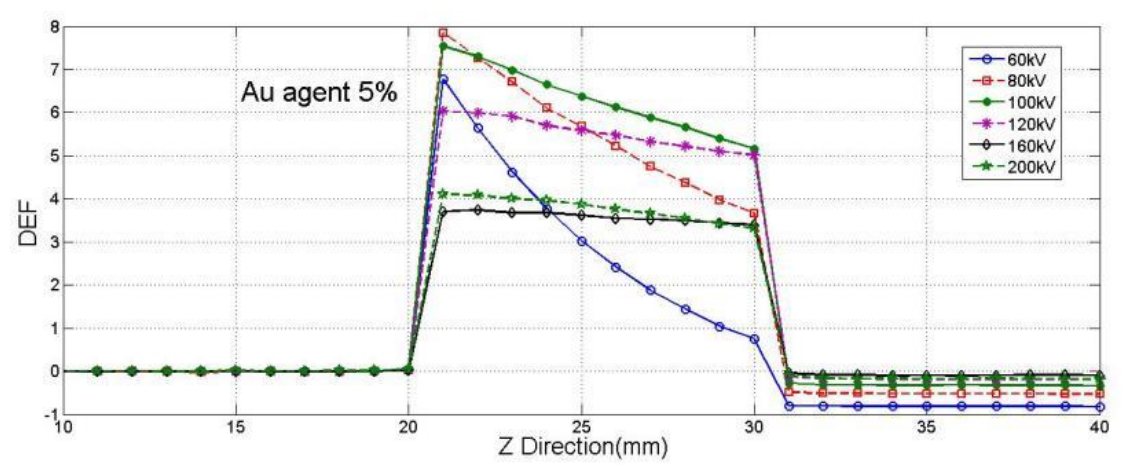

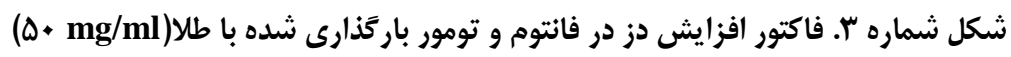




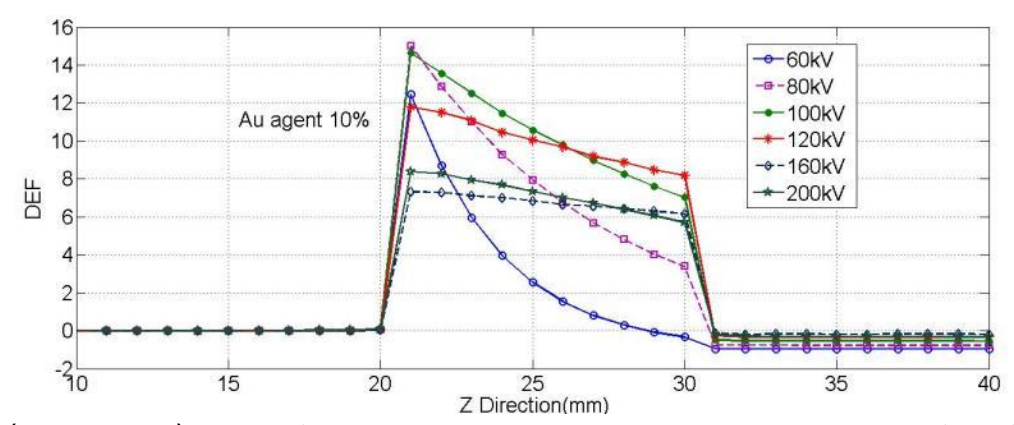

شكل شماره f. فاكتور افزايش دز در فانتوم و تومور بار تذارى شده با طلا( mg/ml +. (1)

تومور، مقدار متوسط DEF تقريباً 1/ إبرابر شده

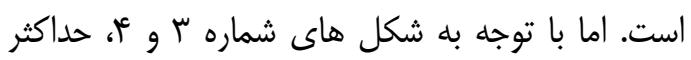

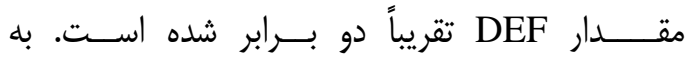

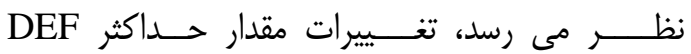

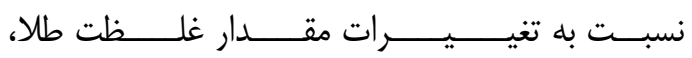

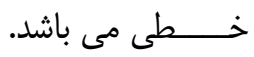

شكل شماره ه مقدار DEF متوسط را در ناحيه تومور بر حسب انرزى موثر فوتون ها(در هر ولتاز لامڤ) براى عنصر طلا نشان مى دهد. حداكثر مقدار

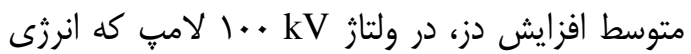

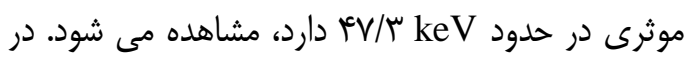

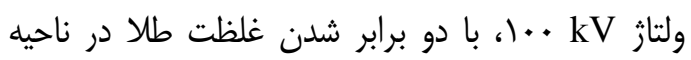

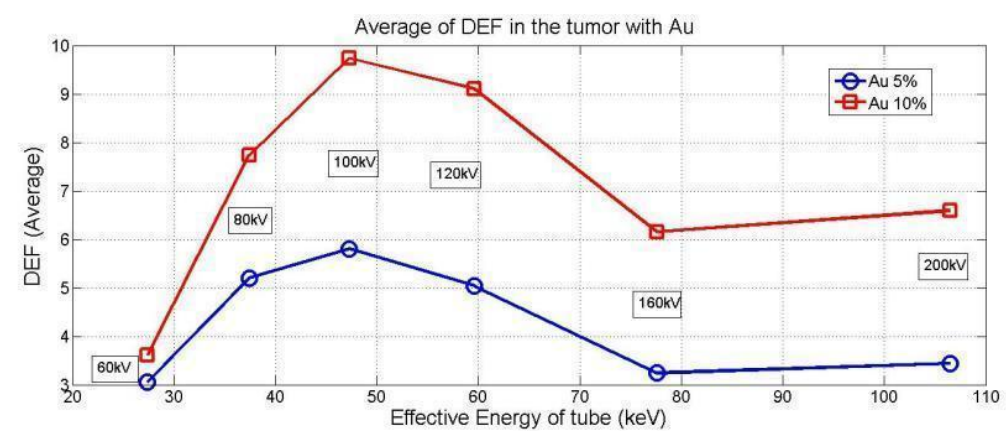

شكل شماره ه. متوسط فاكتور افزايش دز در ناحيه تومور براى طلا

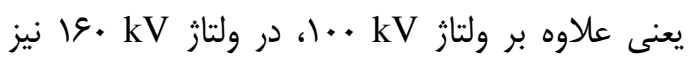
بيشينه وجود دارد. دليل وجود بيشينه دوم، اين است كه فوتون هاى ير انرزى ورودى بله فانتوم، با انجام

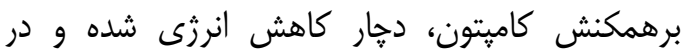
محدوده مناسب براى برهم كنش فوتوالكتريك با ناحيه تومور قرار مى گيرند. در واقع علاوه بر فوتون هاى ماى براي اوليه، فوتون هاى يراكنده شده نيز در تومور، باعث افزايش شديد دز خواهند شد. در مورد طلا، هم اين

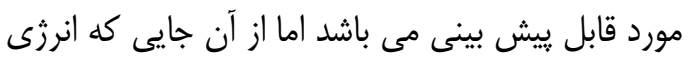

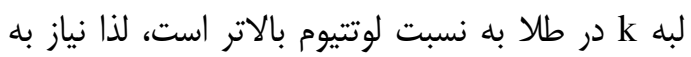

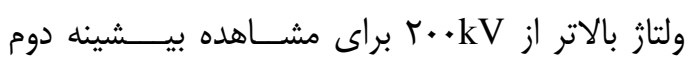
مى باشد. صعود مقدار DEF متوسط براى طالا در ولتاز kV
شكل هاى شماره \& و V مقدار DEF را در نواحى مختلف فانتوم و در راستاى يرتوهاى ايكس براى تئى غلظت هاى ه و •. درصد لوتتيوم و با توجه به ولتاز لامي اشعه ايكس در ناحيه تومور نشان مى دهند. در

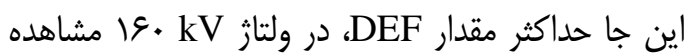
مى شود كه توزيع نسبتاً يكنواختى دارد. البته همانند

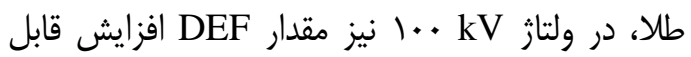

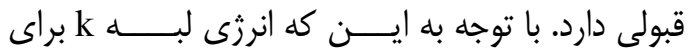

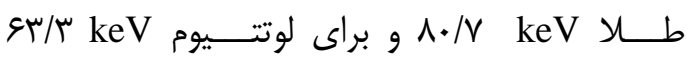
مى باشد، شايد انتظار مى رفت كه براى هر دو عنصر، ولتاز kV +. . ا لامي اشعه ايكس، مقدار بهينه باشد. اما همان طور كه در شكل شماره 1 مشاهده مى شود، متوسط DEF براى لوتتيوم داراى دو بيشينه مى باشد. 


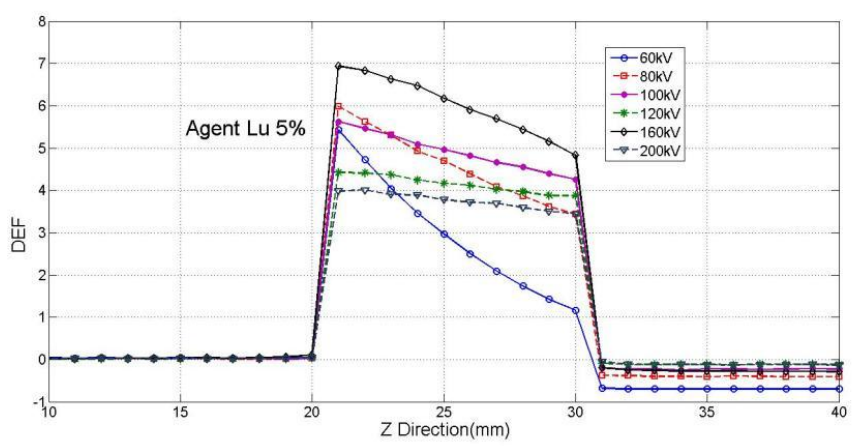

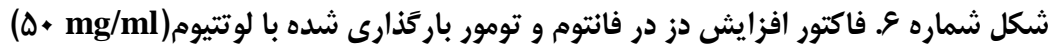

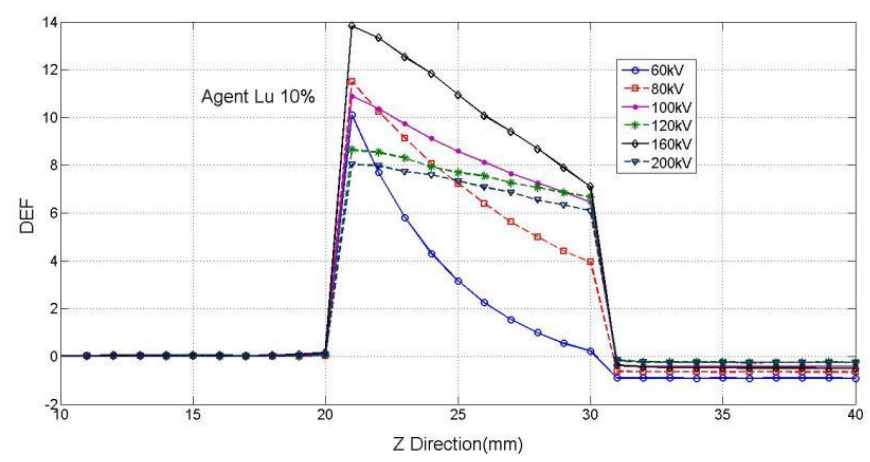

شكل شماره V. فاكتور افزايش دز در فانتوم و تومور باركذارى شده با لوتتيوم( mg/ml + + ( )

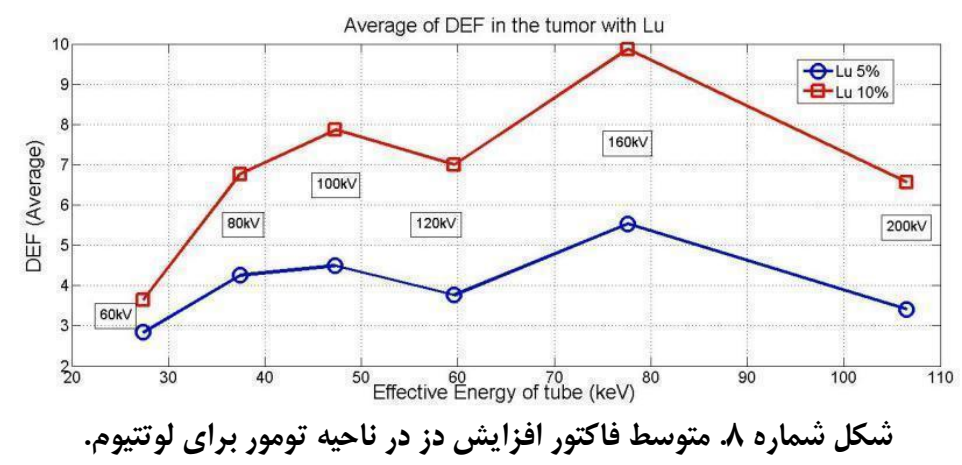

و موجب از بين رفتن سلول هاى سرطانى و تا حد

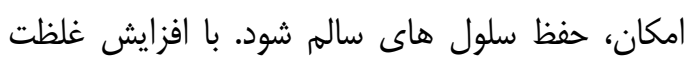
عنصر فعال ساز فاكتور افزايش دز هم افزايش مى سئ يابد.

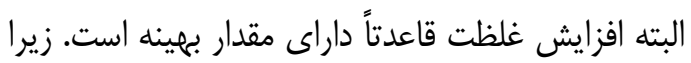
غلظت تا حدى مى تواند افزايش يابد كه به وضعيت سمى براى بدن تبديل نشده و علاوه بر اين توزيع دز در ناحيه تومور حالت يكنواخت داشته باشد كه نتايج

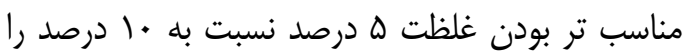
تاييد مى كنند. هر جند در مورد طلا هيج گونه سميتى
شكل هاى شماره و و Vشان مى دهند، با دو برابر شدن غلظت لوتتيوم در تومور، حداكثر مقدار DEF ، همار ، نيز دو برابر شده ولى مقدار متوسط DEF، در ولتـــــازهاى

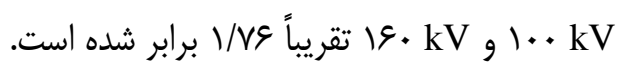
بحث و نتيجه تَيرى اين تحقيق نشان مى دهل، اضافه نمودن يك عنصر فعال ساز فوتونى نظير طلا و لوتتيوم در ناحيه تومور، مى تواند دز اين ناحيه را در مقابل يرتوهاى لطاى ايكس با انرزى مناسب، به صورت انتخابى افزايش داده 


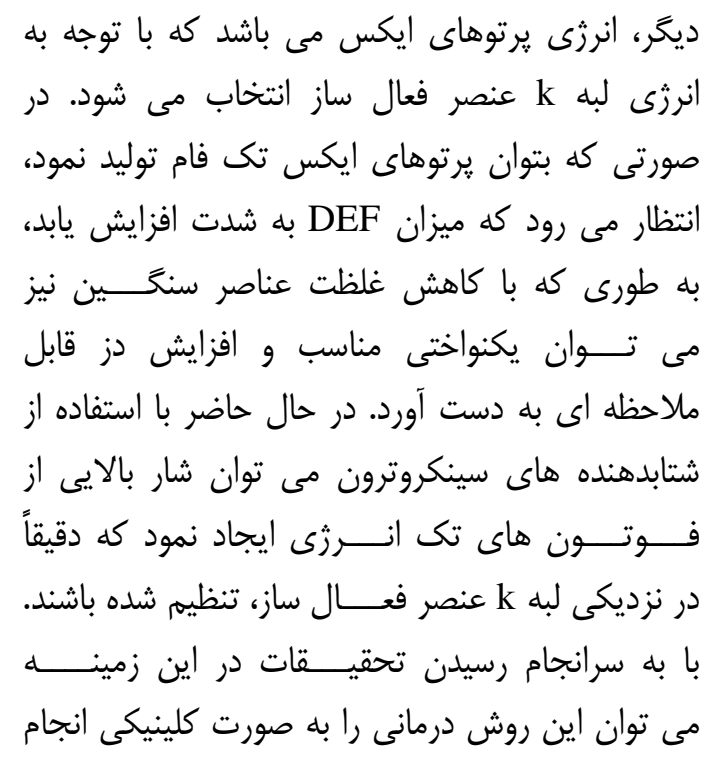

داد.

\section{References}

1. JelvehS, ChithraniD B. Gold nanostructures as a platform for combinational therapy in future Cancer Therapeutics. Cancers2013, 3:1081-110.

2. Choi G, Seo S, Kim K. Photon activated therapy using monochromatic synchrotron $\mathrm{x}$-rays and iron oxide nanoparticles in a Mouse tumor model feasibility study of PAT for treatment of superficial malignancy. Rad Oncol2012, 7:184-93.

3. RezaeiM, Dolat E, Hasanzadeh H. TIO2 nanoparticle as a sensitizer drug in radiotherapy in vitro study. Iranian J Cancer Preve2013, 37-44.

4. Su X, Liu P, Wu H. Enhancement of radio sensitization by metal based nanoparticles in cancer radiation therapy. Cancer Biol Med2014, 11:86-91.

5. Biston MC, Joubert A, Adam JF. Cure of fisher Rats bearing radio resistant $\mathrm{F} 98$ glioma treated with cis-platinum and irradiated with monochromatic synchrotron X-rays. Cancer Res2004, 64: 2317-23.

6. Hainfeld JF, Slatkin DN, Smilowitz HM. The use of gold nanoparticles to enhance radiotherapy in Mice. Phys Med Biol 2004, 49:309-15.

7. Apanasevich V, Avramenko V. Enhance the Absorption of gamma ray energy inside the tumor using gold nanoparticles and iodine particles. Cancer Oncol Res2014; 2:17-20.

8. Ghorbani M, Pakravan D, Bakhshabadi M, Meigooni AS. Dose enhancement in

$$
\begin{aligned}
& \text { كزارش نشده و در مورد لوتتيوم نيز ميزان سميت بسيار } \\
& \text { اندك بوده، به طورى كه مى توان در درمان تومورهاى } \\
& \text { كوجگى نواحى حساس عصبـى و غدد از راديوايزوتـوض } \\
& \text { استفاده كرد(·rVu Lu } \\
& \text { عنصر، يكنواختى دز ناحيه تومور تعيين كننده است كه به بله } \\
& \text { به نظر مى رسد در مورد طلال يكنواختى بيشترى وجود } \\
& \text { دارد اما، لوتتيوم هم به خوبى دز جذ جذبى را در در ناحيه } \\
& \text { تومور فرضى، افزايش مى دهد. بررسى يارامتر عمق نق }
\end{aligned}
$$

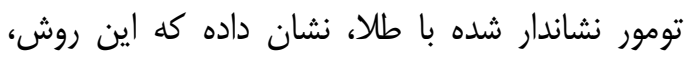

$$
\begin{aligned}
& \text { براى تومورهايى تا عمق ه سانتى متر قابل انجــــام } \\
& \text { مى باشد زيرا با افزايش بيشتر عمق، به دليل كاهش }
\end{aligned}
$$

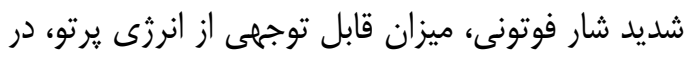

$$
\begin{aligned}
& \text { نواحى قبل از تومور جذب مى شود(آ). يارامتر مهريم }
\end{aligned}
$$

brachytherapy in the presence of gold nanoparticles a monte carlo study on the size of gold nanoparticles and method of modeling. Nukleonika 2012, 57:401-6.

9. Wim H. De J, Werner I, Petra K, Marina C, Adrienne JAM, Robert E. Particle size dependent organ distribution of gold nanoparticles after intravenous administration. Biomaterials2008; 29: 1912-9.

10. Ortega R, Biston MC. Nuclear microprobe determination of platinum quantitative distribution in Rat brain tumors after Cisplatin or carboplatin injection for PAT treatment of glioma. Nucl Meth Phys Res 2005, 231:321-5.

11. Dilmanian FA, Moris GM, Hainfeld JF. Methods for implementing microbeam radiation therapy. US Paten2007; 7:194.

12.Ceresa C, Nicolini G, Requardt H, Duc G, Cavaletti G, Bravin A. The effect of Photon Activation Therapy on cisplatin pretreated human tumour cell lines comparison with conventional $\mathrm{x}$-ray irradiation. J Biol Reg Hom Age 2013, 27:477-85.

13.Taupin F, Flaender M, Delorme R, Brochard T, Mayol JF, Arnaud J, Perriat P, Sancey L. Gadolinium nanoparticles and contrast agent as radiation sensitizers. Phys Med Biol2015; 60:4449-64.

14. Ezzati A O, Mahdavi SR, Anijdan HM. Size effects of gold and iron nanoparticles on radiation dose enhancement in brachytherapy and teletherapy a monte 
carlo study. Iranian J Med Phys2014; 11: 253-9.

15. Hainfeld JF, Slatkin DN, Focella TM, Smilowitz HM. Gold nanoparticles: a new X-ray contrast agent. Br J Radiol 2006; 79:248-53.

16. Chithrani DB, Jelveh S, Jalali F, van Prooijen M, Allen C, Bristow RG, et al. Gold nanoparticles as radiation sensitizers in cancer therapy. Radiat Res2010; 173:719-28.

17. Verhaegen F, Nahum AE, Putte S, NamitoY. Monte carlo modeling of radiotherapy $\mathrm{kV}$ x-ray units. Phys Med Biol1999; 44:1767-89.
18. Amakoa S, Guatellib V, Ivanchenckoc M, Maired B, Mascialinob K. Geant4 and its validation. Nucl Phys 2006; 150: 44-9. 19.Asharani PV, Lianwu Y, Gong Z, Valiyaveettil S. Comparison of the toxicity of silver gold and platinum nanoparticles in developing zebrafish embryos. Biomaterials 2011; 5:43-54.

20. Pillai AM, Knapp FF. Evolving important role of lutetium-177 for therapeutic nuclear medicine. Current Radiopharm 2015, 8:78-85.

21. Ranjbar H, Shamsaei M, Ghasemi M. Investigation of the dose enhancement factor of high intensity low mono energetic $\mathrm{x}$-ray radiation with labeled tissues by gold nanoparticles. Nukleonika 2010, 55:307-12. 


\title{
Increasing The Absorbed Dose in Photon Activation Therapy in the Labeled Tissue by Gold and Lutetium
}

\author{
Ghasemi $M^{l^{*}}$
}

(Received: December 4, 2016

Accepted: February 4, 2017)

\begin{abstract}
Introduction: The Increase in cancer tissues dose while protecting the surrounding healthy tissues is regarded a great challenge in radiotherapy. Photon Activation Therapy (PAT), by introducing high-Z elements to tumor, can enhance the delivered dose in tumor tissues while reducing the dose deposited in adjacent normal tissues. In this study, the effects of various parameters such as X-ray energy, type and concentration of the activation agents in the dose distribution have been investigated to improve the quality of treatment by Geant 4 simulation code.
\end{abstract}

Materials \& Methods: In this study, the effects of introducing $\mathrm{Au}$ and $\mathrm{Lu}$ in targeted tissues irradiated by X-ray beam have been investigated by Geant 4 code. In the designed model, the x-ray source was considered in the shape of a circular plate with the radius of $0 / 5 \mathrm{~cm}$ and the phantom in cubic shape with the side of $15 \mathrm{~cm}$. Rectangular cubic shape detector dimensions are $3 \times 3 \times 7.5 \mathrm{~cm}^{3}$ and the assumed tumor in cubic shape with the side of $1 \mathrm{~cm}$ are located inside it.

Findings: The simulation results were obtained with different voltages of X-ray generator in labeled tumor by $\mathrm{Au}$ and $\mathrm{Lu}$ (with two concentrations of 5 and $10 \mathrm{wt}$. $\%)$. Optimum voltage of $\mathrm{x}$-ray generator in order to maximum Dose Enhancement Factor (DEF) by Au was $100 \mathrm{kV}$, while it was observed at $100 \mathrm{kV}$ and $160 \mathrm{kV}$ for Lutetium. Increasing the absorbed dose for tumor region could reveal the effective role of contrast agents. Furthermore, when the concentration of contrast agents was doubled, average of DEF at the optimum voltage of X-ray generator and in the tumor region, was $1.68 \& 1.76$ for $\mathrm{Au}$ and $\mathrm{Lu}$, respectively.

Discussion \& Conclusions: Based on the results, the absorbed dose in tumor region after introduction of contrast agents with specifying the optimum concentration and photon energy can be increased selectively. This approach of introducing contrast agents could improve the efficiency in the cancerous cells therapy.

Keywords: photon activation therapy, dose enhancement factor, Geant4 code, gold, lutetium

1. Physics and Accelerators Research School, Nuclear Sciences and Technology Research Institute, Karaj, Iran

* Corresponding author Email: mghasemi842@gmail.com

\section{Scientific Journal of Ilam University of Medical Sciences}

